\title{
UPRAVLJANJE INOVACIJSKIM PROMENAMA U SAVREMENOM OKRUŽENJU
}

\author{
Marko Selaković" \\ DOBA - Fakultet za primenjene poslovne i društvene studije, \\ Maribor, Slovenija \\ Nikolina Ljepava**
}

American University in the Emirates, Dubai, Ujedinjeni Arapski Emirati

Milenko Đeletović

Telekom Srbija, Beograd

U okviru ovog preglednog rada sagledani su trendovi i literaturna polazišta u kontekstu upravljanja inovacijama u savremenom okruženju. Analizirano je značenje pojmova invencija i inovacija u aktuelnom trenutku, kao i pojam inovativnosti organizacija. Sagledani su putevi upravljanja procesom transformacije invencija u inovacije, kako se upravlja inovacijama u kontekstu upravljanja promenama. Dat je i osvrt na različite metode poboljšanja invencijskih i inovacijskih procesa u savremenim organizacijama.

Zaključeno je da inovacije predstavljaju jedan od ključnih aspekata ostvarivanja prednosti organizacija. Identifikovane su ključne razlike između pojma invencija i inovacija, kao i između upravljanja invencijama i upravljanja inovacijama. Proces transformacije invencija u inovacije identifikovan je kao kritični izazov u upravljanju organizacijskim razvojem i promenama. U okviru zaključaka rada ukazano je na buduće pravce razvoja inovativnih organizacija, kao i na potrebu da upravljanje inovacijama i upravljanje promenama budu bazirani na organizacijskom znanju. Izložen je predlog sistema i struktura koje se u savremenim organizacijama mogu koristiti za efikasno upravljanje inovacijama, i identifikovane oblasti koje daju mogućnosti za dalji naučno-istraživački rad usmeren ka istraživanju ove teme.

Ključne reči: inovacije, invencije, upravljanje inovacijama, upravljanje promenama, upravljanje znanjem

\section{Inovacije i inovativnost}

Sosobnost organizacija da upravljaju inovacijama predstavlja jednu od njihovih

ključnih konkurentskih prednosti (Kostadinović \& Petrović-Ranđelović, 2015; Likar \& Fatur, 2007). Kreiranje novih šansi kroz inovacije, u konkurentski i tehnološki sve intenzivnijem okruženju, je u sve većoj i većoj meri ključni faktor poslovnog uspeha (Stan-

\footnotetext{
*marko.selakovic@new.doba.rs

** Doc. dr. Nikolina Ljepava, nikolina.ljepava@aue.ae
} 
ković et al, 2011). Ovaj aspekt posebno je značajan kada je u pitanju sektor usluga. Globalizacija tržišta, ubrzanje poslovnih procesa, tehnološki razvoj i aktivnosti konkurencije uslovljavaju kompanije da kontinuirano inoviraju kako bi zadržale ravnopravno učešće u tržišnoj utakmici, i to kako ne bi bile istisnute sa lokalnog tržišta i kako bi bile u mogućnosti da se proširuju na druga tržišta (Milojević et al, 2016).

$\mathrm{Na}$ osnovu veličine promena koje sa sobom nose, inovacije se, prema Drucker (1985), mogu podeliti na:

1) Epohalne inovacije, koje drastično menjaju pravila igre na tržištu i globalne tokove;

2) Konzervativne inovacije, koje uvode manje, ali korisne promene u svakodnevni život;

3) Inovacije zasnovane na diferencijaciji, koje izdvajaju određeni proizvod ili uslugu u odnosu na ostale aktere na tržištu.

Uprkos tehnološkom napretku i konstantnoj tržišnoj utakmici koja podsticajno utiče na inovativnost, nisu sve organizacije u jednakoj meri spremne da inoviraju. Hii i Nealy (2000) uvode pojam inovacionog kapaciteta, ocenjujući da su organizaciona kultura, resursi, kompetencije i umreženost ključni i centralni preduslovi za jačanje inovativnosti (Grafikon 1). Svaki od navedenih faktora igra značajnu ulogu u razvoju i sprovođenju inovacija u određenoj kompaniji. Brojni autori obrađuju problematiku prepreka za ostvarenje inovativnosti. One mogu biti ekonomske/finansijske prirode, organizacione, institucionalne ili kontekst-specifične (lammarino et al, 2009). Prema Stanković et al. (2011), neadekvatna strategija i odsustvo poslovnog modela koji stimuliše inovativnost predstavljaju najsnažnije prepreke za razvoj inovativnosti, posebno u sektoru malih i srednjih preduzeća. Hii i Nealy (2000) apostrofiraju organizacionu kulturu kao ključnu prepreku, dok Blanchard et al. (2013) ukazuju da treba na različiti način sagledavati problematiku i prepreke kod organizacija koje ne žele uopšte da inoviraju, u odnosu na one koje su obeshrabrene da sprovode inovacije zbog negativnih iskustava iz ranije prakse.

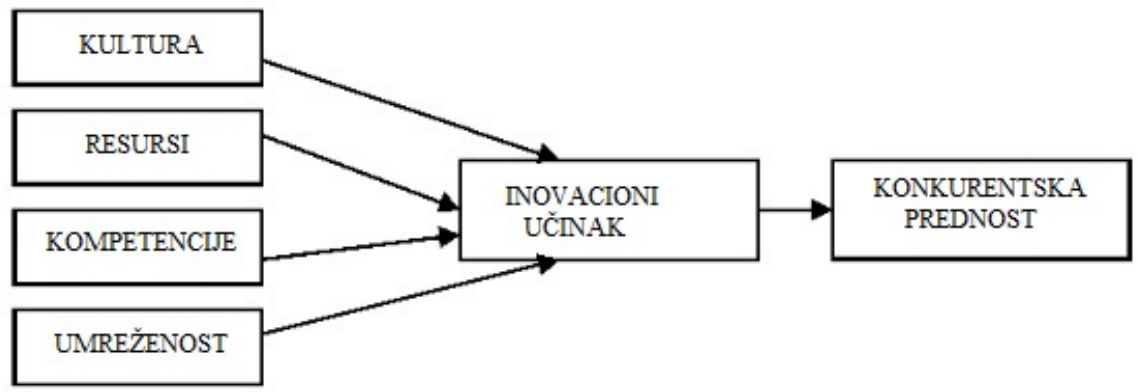

Grafikon 1 - Inovacioni kapacitet (prema Hii \& Nealy, 2000)

Mnogobrojni kofaktori utiču na inovativnost organizacije. Bez ikakve sumnje, adekvatno upravljanje znanjem jedan je od neophodnih preduslova za povećanje inovativnosti i konkurentnosti organizacije (Punia, 2014; Radovanović, 2014). Znanje, kao ekonomski resurs, po svojoj prirodi teži da sadrži sposobnost da utiče na ideje i inovacije (Likar \& Fatur, 2007). U savremenoj ekonomiji, osnovni ekonomski resurs nisu više ni kapital, ni prirodni resursi, niti rad - već znanje. Nova znanja, promene u percepciji i neočekivani događaji takođe su izvori inovacija (Drucker, 1994). Akumulirano i apsorbovano znanje pohranjeni unutar organizacije mogu biti katalizatori inovacija (Radovanović, 2014). 
Efikasna komunikacija i dobra interna komunikaciona klima mogu pobuditi inovativnost u organizaciji (Radovanović, 2014). Postojanje sistema upravljanja znanjem pozitivno se odražava na mnoge organizacijske procese, uključujući i upravljanje promenama (Selaković, 2017). Takođe, strateški pristup upravljanju razvojem brenda pokazao je pozitivne implikacije na povećanje konkurentnosti, a samim tim i inovativnosti (Mandarić, 2012).

\section{Pojmovi invencije i inovacije}

Pojmovi invencije i inovacije neraskidivo su vezani za organizacije koje žele da kroz transformacije dolaze do konkurentskih prednosti. Pre bilo kakvih daljih razmatranja, najpre treba otkloniti semantičku dilemu: invencija i inovacija nisu sinonimi (Teodorescu, 2015).

Invencija je nova, originalna zamisao koja poseduje potencijal da bude korisna (Likar \& Fatur, 2007). U osnovi invencije je ideja, koncept, odnosno metod za uvođenje novog proizvoda, usluge, procesa ili sistema (Likar \& Fatur, 2007; Teodorescu, 2015). Invencija po svojoj prirodi predstavlja ishod mentalnog procesa konceptualizacije (Teodorescu, 2015) i može se posmatrati kao nova ideja koja poseduje određeni potencijal da se razvije i transformiše u inovaciju. Prema Čovo \& Maruna (2013), invencija je prvi korak u kojem dolazi do koncepta nove ideje i kreiranja mogućnosti za inovaciju; pre dalje transformacije, svaka invencija mora da prođe test realnosti (Brockner et al, 2004).

Invencija se može pojaviti kao plod teorijskih uvida, analize podataka, metoda ili potreba (Stefik \& Stefik, 2004). Sa druge strane, inovacija je rezultat kreativnog procesa konverzije invencije u novi proizvod i biznis (Teodorescu, 2015).

Inovacija je, prema Čovo \& Maruna (2013), svaki novi proizvod, usluga, proces, tehnologija nastala primenom vlastitih ili tuđih rezultata naučno-istraživačkog rada, odnosno otkrića i saznanja, kroz ideju ili metode za njeno stvaranje, koja je sa odgovarajućom vrednošću plasirana na tržište. Inovacija može imati različite oblike i može se pojavljivati u različitim fazama i nivoima, ali na kraju mora imati upotrebnu vrednost (Likar \& Fatur, 2007).

Invencija i inovacija su organski povezani pojmovi; invencija bez inovacije predstavlja puku imaginaciju, ukoliko nije preuzeta iz drugog okruženja i adaptirana, inovacija bez invencije kao prekursora predstavlja tek sterilnu proceduru koja se na kraju ispostavi beskorisna po organizaciju (Teodorescu, 2015). U praksi, najveći broj inovacija proizilazi iz invencija (Williams, 1999).

\section{Transformacije invencija u inovacije}

Invencija je prva faza procesa inovacije (Brigić, 2014; Čovo \& Maruna, 2013; Williams, 1999; Thompson, 1965; Likar \& Fatur, 2007). Međutim, put od invencije do inovacije je višestepen i može biti linearan, ili nelinearan (Dooley, 2004).

Najčešće se proces inovacije posmatra kroz nekoliko faza: invencija, razvoj, difuzija, integracija (Thompson, 1965); invencija, razvoj, difuzija, integracija i praćenje (Brigić, 2014). Prema nekim razmatranjima (Palmberg, 2006), fazi invencije u pojedinim slučajevima prethodi faza utvrđivanja tržišnih potreba, ali ona, u kontekstu razmatranja Stefik \& Stefik (2004), predstavlja tek jedan od mogućih uslova za pojavu invencije, te se proces 
konverzije u inovacije ipak može konzervativno posmatrati, prihvatajući stav Thompson (1965) da je invencija predominantno prvi korak u nastajanju inovacije. Sa druge strane, inovacija treba da predstavlja novost za datu organizaciju i njeno okruženje: ona ne mora biti jedinstvena u globalnom kontekstu. Inovacija treba da bude jedinstvena i nova za ekosistem u kojem određena organizacija posluje, ali ona ne mora uvek nužno proizaći iz invencije: inovacija može predstavljati i replikaciju rešenja primenjenog od strane druge organizacije u drugom ekosistemu.

Prema Thompson (1965), faze inovacije su:

- Invencija - zamisao o novom proizvodu ili procesu; u rudimentalnom obliku.

- Razvoj - dalje testiranje pomoću kojeg se invencija modifikuje, dopunjava i razrađuje do najsitnijih detalja u cilju tehnološke pripreme za praktičnu aplikaciju

- Inovacija - usvajanje finalizovane verzije i njena prva praktična upotreba, i

- Difuzija - nivo koji se odnosi na stepen i brzinu kojom inovacija prelazi u široku upotrebu, dok druge kompanije ulaze u ciklus sleđenja inovatora.

Brigić (2014) u svojim razmatranjima dodaje i petu fazu - praćenje inovacije. Međutim, ovo gledište se ne može prihvatiti kao nužno ispravno: faza monitoringa primene inovacija neminovno se prepliće sa narednom invencijom, istraživanjem i razvojem, iz čega može proizaći nova inovacija (Tao et al, 2010; Aggeri, 1999). Otuda deluje realnije gledište da inovacija svoj životni ciklus završava ili nestajanjem ili ponavljanjem (Hosteter \& al, 2014). Životni ciklus inovacije obuhvata iniciranje, mapiranje ideje i pilotiranje u inicijalnoj fazi, te operacionalizaciju, optimizaciju i nestajanje ili ponavljanje, u drugoj fazi. Operativna faza transformacije nastupa nakon prevazilaženja „O“ prepreke („O-Gap“), tokom koje organizacija treba da stvori uslove za pretakanje ideje u delo (Hosteter et al, 2014). Celokupni životni ciklus inovacije prikazan je na Grafikonu 2:

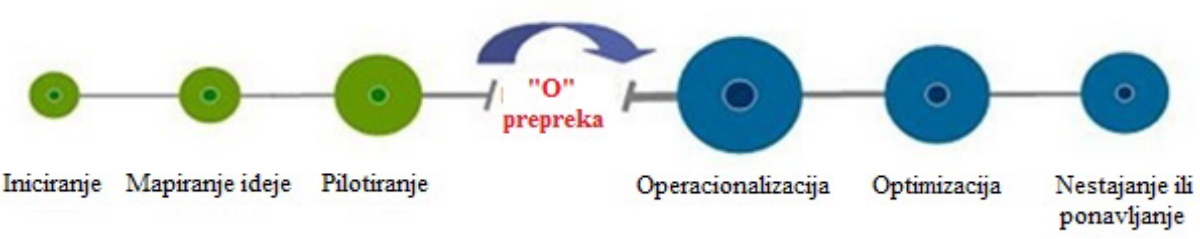

Grafikon 2 - Životni ciklus inovacije (prema Hosteter et al, 2014)

Evidentno je da transformacija invencija u inovacije obuhvata veći broj aktivnosti, od traženja i razrade novih ideja, preko pripreme rešenja do ulaska na tržište, primene i monitoringa efekata inovacije. Ovaj proces može se izvoditi na različite načine i u velikoj meri zavisi od karakteristika same organizacije (Desouza et al, 2009), a postojanje sistema upravljanja idejama od ključnog je značaja za uspešno odvijanje ovog procesa (Likar \& Fatur, 2007). Cameron (2004) smatra da je postojanje jasnog „inovacijskog cevovoda“ unutar organizacije ključno za održivost inovacija i uspešnu transformaciju invencija u inovacije. Ovaj koncept obuhvata invenciju, validaciju, inkubaciju i investiranje, implementaciju i komercijalizaciju i merenje sa nagrađivanjem kao faze uvođenja inovacije u kontekstu poslovnih procesa i promena (Cameron, 2004). Prikaz koncepta „inovacijskog cevovoda" zasnovanog na kontinuiranom praćenju performansi dat je na Grafikonu 3: 
Invencija Validacija Inkubacija Implementacija Merenje

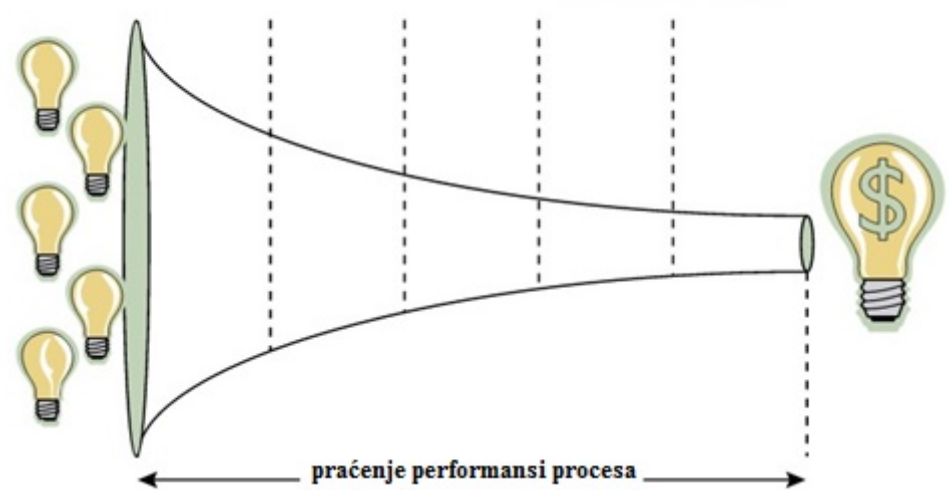

Grafikon 3 - Koncept i funkcija "Inovacijskog cevovoda" (prema Cameron, 2004)

\section{Metode za poboljšanje invencijsko-inovacijskih procesa}

Kontinuirano inoviranje je novo ime za upravljanje promenama u industrijskoj i tržišnoj utakmici u ekonomiji znanja. Međutim, proces upravljanja i poboljšanja procesa kontinuiranog inoviranja predstavlja izazov za brojne kompanije na tržištu (Boer \& Gertsen, 2003).

U današnje vreme, korisnici zahtevaju široku paletu proizvoda ili usluga sa pristupačnom cenom i visokim kvalitetom, koji su pri tom visoko specifično prilagođeni njihovim potrebama, te isporučeni brzo i pravovremeno (Bolwijn \& Kumpe, 1998). Ovakvo očekivanje za svoju posledicu ima da organizacije moraju da prođu kroz proces promena, odnosno da usklade svoju operativnu efikasnost i stratešku fleksibilnost (Boer \& Gertsen, 2003). Zapravo, u 21. veku organizacije po svojoj prirodi moraju biti inovativne; od njih potrošači očekuju jedinstvenost, a inovativnost postaje jedna od osnovnih determinanti učinka kompanija. Prikaz razvoja različitih organizacionih formi kroz vreme (prema Boer \& Gertsen, 2003; Bolwijn \& Kumpe, 1998) dat je na Grafikonu 4:

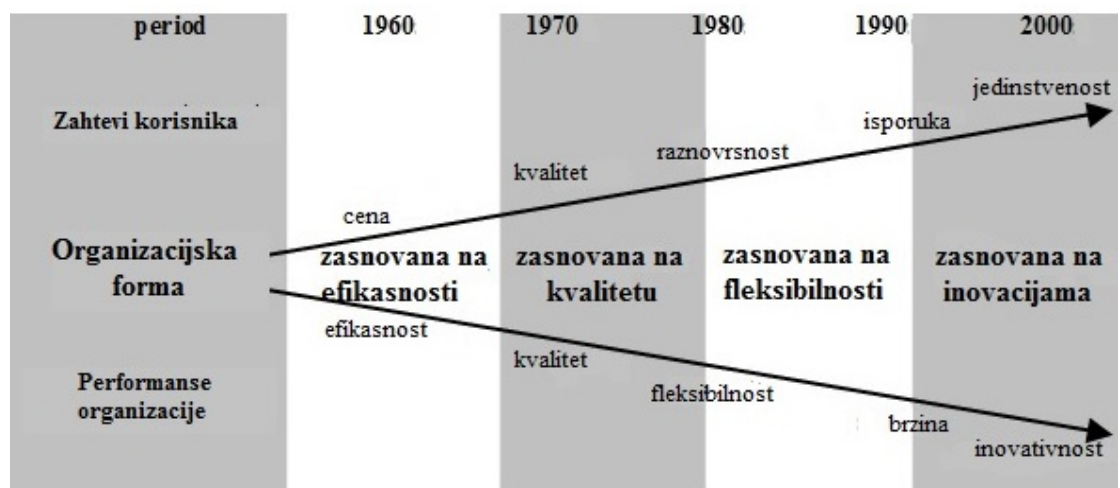

Grafikon 4 - Razvoj organizacione forme kroz vreme (Boer \& Gertsen, 2003; Bolwijn \& Kumpe, 1998) 
Ipak, neophodnost kontinuiranog inoviranja nameće pred organizacije i izazove upravljanja drugim dualnim balansima. Pored operacione efikasnosti i strateške fleksibilnosti (Boer \& Getsen, 2003), Boer et al. (2006) identifikuju još tri dualna odnosa u kojima organizacija mora uspostaviti balans kako bi se stvorili preduslovi za kontinuirano inoviranje i istovremeno unapređenje invencijsko-inovacijskih procesa. Ove dualnosti su:

- Eksploatacija i eksploracija;

- Stabilnost i obnova;

- Akcija i refleksija na sistem, odnosno organizaciju.

Na navedene izazove upravljanja i balansiranja dualnosti organizacija može odgovoriti različitim oblicima koordinacije (Boer et al, 2006), ali i drugim aktivnostima, poput kontinuiranog unapređenja i učenja (Boer \& Gertsen, 2003). Ako se uzme u obzir da je kontinuirano inoviranje zapravo „odvijajuća interakcija između operacija, inkrementalnog unapređenja, učenja i radikalnog inoviranja sa ciljem efektivnog kombinovanja operacione efikasnosti i strateške fleksibilnosti, odnosno eksploatacije i eksploracije" (Boer \& Gertsen, 2003, str. 807), jasno je da svaka organizacija koja pledira da uspostavi koncept kontinuiranog inoviranja i unapređenja invencijsko-inovacijskih procesa mora da razvije mehanizme kombinovanja efikasnosti, kvaliteta, fleksibilnosti, brzine i inovativnosti (Boer \& Gertsen, 2003).

Upravljanju procesima upravljanja promenama, kontinuiranog inoviranja, kao i kontinuiranog unapređenja invencijsko-inovacijskih procesa korisno je pristupiti holistički; bilo kakvo upravljanje koje bi se fokusiralo primarno samo na jedan razvojni aspekt ne može obezbediti kontinuirani napredak (Roberts, 2007). Ovo razmatranje posebno dobija na značaju kada se sagleda da je inovativnost jedna od ključnih karakteristika kompanija sa liderskom pozicijom na tržištu (Likar \& Fatur, 2007; Simon, 2009).

Prema Lane \& Flagg (2010), kontinuirano unapređenje invencijskih i inovacijskih procesa su procesi prisutni u savremenim organizacijama. Oni se odvijaju i ponavljaju ciklično i zasnovani su na transformaciji znanja unutar organizacije, ali se po svojoj prirodi razlikuju: proces kontinuiranog unapređenja invencija bavi se pre svega testiranjem i validacijom, uz sagledavanje barijera koje postoje u razvoju invencije. Sa druge strane, ciklus kontinuiranog unapređenja inovacija zalazi u domen dubljih organizacijskih i tržišnih promena, uz neophodnost brižljivog planiranja, testiranja i permanentnog monitoringa performansi inovacije na tržištu.

Razlika između koncepta kontinuiranog poboljšanja procesa invencije i kontinuiranog poboljšanja procesa inovacije, uočena od strane Lane \& Flagg (2010), je po prirodi stvari logična, jer literatura ukazuje da se i sami pojmovi invencije i inovacije po svojoj prirodi razlikuju (Likar \& Fatur, 2007; Teodorescu, 2015). Ipak, uočljive se i paralele između invencija i inovacija u modelu Lane \& Flagg (2010): oba ciklusa baziraju se na principu kontinuiranog poboljšanja, i uključuju ljudski faktor u procesu kreiranja.

Pojedinac igra ključnu ulogu u generisanju ideja i daljem razvoju invencije, ali je za organizaciju poželjno da invencijski i inovacijski procesi budu strukturirani u najvećoj mogućoj meri. Široka participacija zaposlenih preduslov je za očuvanje i unapređenje kontinuirane inovativnosti organizacija (Tonnessen, 2005). Tehnika održavanja internih sastanaka i „brainstorming“ tehnika pokazali su se kao najčešće korišćene u procesu kontinuiranog unapređenja invencija i inovacija (McAdam \& McClelland, 2002).

Metode internih sastanaka i brainstorming-a korisne su ne samo u pogledu direktne razmene ideja i zajedničkog rada na stvaranju invencija i daljem sprovođenju inovacija; one su od značaja u deljenju i razmeni tacitnog znanja i njegovoj konverziji u organizacij- 
sko eksplicitno znanje (Johanessen et al, 1999). Navedeni aspekti su od posebnog značaja, imajući u vidu da su inovacije u organizacijama utemeljene na znanju (SabolovićKrajina, 2015), te da su inovacije u sve većoj meri rezultat timskog rada (Prester, 2010).

Postoje i dodatni mehanizmi unapređenja invencijsko-inovacijskih procesa: organizacije koje teže kontinuiranom unapređenju inovativnosti treba da stvore optimalne uslove za razvoj ideja i unapređenje sposobnosti zaposlenih da stvaraju nove ideje i invencije (Albers \& Brewer, 2003). Organizacije mogu podsticati kod zaposlenih razmišljanje van okvira („outside the box“), ili stvarati diverzitet koji vodi ka inovativnosti (Hewlett et al, 2013). Mala i srednja preduzeća koja žele da se liderski pozicioniraju u ekonomijama u razvoju mogu koristiti i metode projektovanja budućnosti (foresight), kako bi pospešile i poboljšale odvijanje invencijsko-inovacijskih procesa (Ejdys, 2014). Dodatno, kompanije mogu u izboru osoblja voditi računa da ono ispunjava kriterijume i kritične uloge za uspešno sprovođenje invencijsko-inovacijskih procesa (Roberts, 2007).

\section{Upravljanje inovacijama u kontekstu upravljanja promenama}

Inovacije po svojoj prirodi predstavljaju kompleksan i višefazni proces (Likar \& Fatur, 2007). Logično, kompleksnost procesa inoviranja postavlja i specifične izazove u upravljanju. Pojam upravljanja inovacijama u organizaciji obuhvata „planiranje, organizovanje, koordinaciju i kontrolu inovacionih procesa i inovacija - od ideje do realizacije" (Stošić \& Jeremić, 2007, str. 42).

Proces uvođenja organizacione promene, ili uvođenja novog proizvoda ili usluge je težak i uspešnost vođenja i menadžmenta zavisi od mnogobrojnih različitih faktora. Balachandra i Friar (1997) ukazuju da uspešnost vođenja inovacija zavisi od okruženja, tržišta, same organizacije i tehnologije. Ovo razmatranje može se uzeti u obzir kada je reč o vođenju inovacija unutar organizacije; ukoliko se razmatra vođenje inovacija koje po svojoj prirodi u sebi inkorporiraju i učešće eksternih organizacija, ili koje se po svojoj prirodi prostiru na više organizacija, komunikacija i efikasna razmena između organizacija, koja rezultira transformacijom i integracijom znanja u komercijalnu inovaciju, je ključni preduslov za uspešno vođenje inovacija (Easterby-Smith et al, 2008).

Informaciono-komunikacione tehnologije otvorile su nove mogućnosti kada je reč o upravljanju promenama i vođenju inovacija. Korišćenje informacionih tehnologija samo po sebi predstavlja inovativan način rada za mnoge organizacije i rukovodioce (Martin \& Matlay, 2003). Informacione tehnologije stvorile su mogućnosti za brze organizacijske promene, generisanje i nadogradnju organizacijskog znanja i efikasnije upravljanje znanjem (Newell et al, 2009; Selaković, 2017). Uvođenje novih internih komunikacijskih alata može pokrenuti zaposlene (Malouf et al, 2016). Svi ovi faktori pogodno utiču na razvoj upravljanja inovacijama u organizacijama, jer nova paradigma upravljanja znanjem, zasnovana na akumulaciji i deljenju znanja korišćenjem informaciono-komunikacionih tehnologija, daje potporu za primenu nove paradigme upravljanja inovacijama (Chiaroni et al, 2011).

Uspešno upravljanje inovacijama podrazumeva koordinaciju portfolija razvojnih projekata sa u okviru jasne inovativne platforme, koja stoji u saglasju sa sveopštom poslovnom strategijom organizacije (Flynn et al, 2003). Stošić i Jeremić (2007), te Stošić (2007) definišu ključne elemente koji su obuhvaćeni procesom upravljanja inovacijama: 
Upravljanje sistemima

„1. Definisanje inovacione strategije i njeno usklađivanje sa drugim strategijama

2. Upravljanje portfoliom za selekciju inovacionih projekata;

3. Generisanje ideja i kretanja znanja usmerenih na nove i usavršene proizvode, procese, usluge, tehnologije, organizaciju, marketing itd.

4. Razvoj ideja kroz radne prototipe,

5. Prenošenje ideja u proizvodnju, distribuciju i upotrebu,

6. Razvoj sistema podsticaja inovacija i utvrđivanje inovacionih performansi“ (Stošić \& Jeremić, 2007, str. 42).

Definisanje inovacijske strategije predstavlja jedan od ključnih faktora poboljšanja uspešnosti organizacije (Cooper \& Edgett, 2006). Organizacije koje su definisale inovacijsku strategiju i povezale inovacijske projekte sa sveopštom strategijom razvoja imaju značajnu prednost u dostizanju radikalne inovativnosti u odnosu na one koje ne pribegavaju ovim rešenjima (Knoskova, 2015).

Upravljanje inovacijskim portfoliom poseban je izazov za organizacije. Uspešnost upravljanja inovacijskim portfoliom zavisi od selekcije projekata, ali i od alokacije resursa za sprovođenje inovativnih projekata (Klingebiel \& Rammer, 2014). Ernst i Lichtenthaller (2009) smatraju da je upravo uspešno upravljanje inovacionim portfoliom ključni faktor uspešnog vođenja inovacija u organizacijama.

Generisanje ideja i adekvatno upravljanje idejama jedan su od ključnih faktora za povećanje inovativnosti kompanija (Likar \& Fatur, 2007). U te svrhe, organizacija treba da pospešuje i podstiče kreativnost, kao prekursor generisanja ideja, na svim nivoima (Lawson \& Samson, 2001). lako su organizacije neretko dobre u generisanju ideja, inovacijski proces i upravljanje inovacijama postavljaju daleko šire zahteve od samog generisanja ideja (Birkinshaw et al, 2011).

Razvoj ideja kroz radne prototipe prisutan je u mnogim kompanijama koje u sebi imaju odeljenja za istraživanje i razvoj. Ovde se često javlja matrično organizaciono upravljanje, u kojem postoji dvojaka koordinacija: na nivou rukovodioca inovacionog tima, i na nivou rukovodioca odeljenja (Souder, 1988). Međutim, mnoge kompanije u uslužnoj delatnosti, čak i kada je reč o međunarodnim kompanijama, nema formirana specifična odeljenja za istraživanje i razvoj, već se upravljanje inovacijama vrši u okvirima različitih odeljenja u okviru organizacije (Komninos et al, 2006).

Prenošenje ideja u proizvodnju i upotrebu sastavni je deo procesa upravljanja inovacijama (Likar \& Fatur, 2007). Ovaj aspekt detaljno je opisivan u poglavlju „Faze transformacije invencija u inovacije" (str. 7).

Uz stvaranje podsticajnog ambijenta za inoviranje od strane zaposlenih, što, uz sistem motivacije i nagrađivanja inovativnog razmišljanja predstavlja značajan aspekt uspešnog upravljanja inovacijama (Trott, 2008; Hewlett et al, 2013), organizacije koriste različite forme kako bi na što efikasniji način pristupile vođenju inovacija. Pored već opisanih jedinica za inovacione aktivnosti, odnosno odeljenja za istraživanje i razvoj, te matrične organizacije, u vođenju inovacija u sektoru usluga prisutni su i multiprojektni menadžment, u kojem se simultano upravlja većim brojem razvojnih projekata (Maniak \& Midler, 2014), virtuelni timovi, čiji rad se odvija u virtuelnom Internet prostoru i koji rade na vođenju inovacija uz korišćenje informaciono-komunikacionih tehnologija za međusobnu komunikaciju i razmenu ideja (Jarle Gressgard, 2011), te „New Venture Unit“ - strukture koje su po pravilu autonomne u odnosu na organizaciju, a koje se namenski bave vođenjem inovacija koje mogu biti visoko rizične po organizacijski učinak ili reputaciju (Bart, 1988). 


\section{Zaključci}

$\mathrm{Na}$ osnovu pregleda raspoložive literature i sagledavanja aktuelnog konteksta upravljanja promenama, upravljanja inovacijama i upravljanja znanjem, mogu se u okviru ovog rada izvesti sledeći zaključci:

- Upravljanje inovacijama krucijalno je značajno za funkcionisanje savremenih organizacija. U ekonomijama zasnovanim na znanju, upravljanje inovacijama je kritični faktor obezbeđivanja konkurentskih prednosti organizacija.

- Upravljanje invencijama i upravljanje inovacijama predstavljaju različite upravljačke procese. Sam proces transformacije invencija u inovacije predstavlja kritični izazov u upravljanju organizacijskim razvojem i promenama.

- Inovacije imaju mnogostruke organizacijske implikacije. Između ostalog, svaka inovacija sama po sebi implicira promene u različitim oblicima organizacijskog delovanja i ponašanja. Otuda su pojmovi upravljanja promenama i upravljanja inovacijama međusobno neodvojivi.

- Budućnost organizacija usmerena je u pravcu stvaranja inovativnih organizacija. Organizacione promene omogućuju transformaciju iz fleksibilnih modela u inovativne organizacijske modele.

- Mnogobrojne metode poboljšanja kako invencijskih, tako i inovacijskih procesa, obezbeđuju kontinuirano unapređenje inovacionih performansi organizacija.

- U savremenom organizacijskom okruženju, upravljanje inovacijama, kao i upravljanje promenama, treba da budu bazirani na organizacijskom znanju i ovi procesi su u savremenim organizacijama međusobno prožeti.

- Za efikasno upravljanje inovacijama, savremene organizacije mogu koristiti sledeće sisteme i strukture:

a) Jedinice za inovacione aktivnosti,

b) Odeljenja za istraživanje i razvoj, te matrične organizacije,

c) Multiprojektni menadžment,

d) Virtuelne timove,

e) Jedinice za razvoj novih poslova (New Venture Unit).

U budućem istraživanju moguće je staviti dodatni akcenat na upravljanje organizacijskim znanjem u kontekstu inovacionih promena, kao i na detaljnije sagledavanje uloge inovacija u oblikovanju savremenih organizacija i sistema.

\section{Literatura}

[1] Aggeri, F. (1999). Environmental policies and innovation: A knowledge-based perspective on cooperative approaches. Research policy, 28(7), 699-717.

[2] Albers, J. A., \& Brewer, S. (2003). Knowledge management and the innovation process: the eco-innovation model. Journal of Knowledge Management Practice, 4(6), 1-6.

[3] Balachandra, R., \& Friar, J. H. (1997). Factors for success in R\&D projects and new product innovation: a contextual framework. IEEE Transactions on Engineering management, 44(3), 276-287.

[4] Bart, C. K. (1988). New venture units: Use them wisely to manage innovation. MIT Sloan Management Review, 29(4), 35.

[5] Birkinshaw, J., Bouquet, C., \& Barsoux, J. L. (2011). The 5 myths of innovation. MIT Sloan Management Review, 52(2), 43. 
[6] Blanchard, P., Huiban, J. P., Musolesi, A., \& Sevestre, P. (2013). Where there is a will, there is a way? Assessing the impact of obstacles to innovation. Industrial and Corporate Change, 22(3), 679-710.

[7] Boer, H., \& Gertsen, F. (2003). From continuous improvement to continuous innovation: a (retro)(per) spective. International Journal of Technology Management, 26(8), 805-827.

[8] Boer, H., Kuhn, J., \& Gertsen, F. (2006). Continuous innovation: managing dualities through co-ordination. Continuous Innovation Network. WPS, 1.

[9] Bolwijn, P. T., \& Kumpe, T. (1998). Marktgericht ondernemen. Uitgeverij Van Gorcum.

[10] Brigić, M. (2014). Odnos između strategije izvorne inovativnosti i rasta proizvodnih preduzeća. Business Consultant/Poslovni Konsultant, 6(40).

[11] Brockner, J., Higgins, E. T., \& Low, M. B. (2004). Regulatory focus theory and the entrepreneurial process. Journal of Business Venturing, 19(2), 203-220.

[12] Cameron, B. (2004). IT Can Help Accelerate Business Innovation. Innovation-Forrester Research.

[13] Chiaroni, D., Chiesa, V., \& Frattini, F. (2011). The Open Innovation Journey: How firms dynamically implement the emerging innovation management paradigm. Technovation, 31(1), 34-43.

[14] Cooper, R. G., \& Edgett, S. J. (2006). Ten ways to make better portfolio and project selection decisions. PDMA Visions Magazine, 30(3), 11-15.

[15] Čovo, P., \& Maruna, M. (2013, October). Logistics of intellectual property. In 4. konferencija Inovacijama do konkurentnosti "Inovacije, intelektualno vlasništvo i nagrađivanje inovatora".

[16] Desouza, K. C., Dombrowski, C., Awazu, Y., Baloh, P., Papagari, S., Jha, S., \& Kim, J. Y. (2009). Crafting organizational innovation processes. Innovation, 11(1), 6-33.

[17] Dooley, K. J. (2004). Complexity science models of organizational change and innovation. Handbook of organizational change and innovation, 354-373.

[18] Drucker, P.F. (1985). Innovation and Entrepreneurship: Practice and Principles. AMACON.

[19] Drucker, P. F. (1994). Post-capitalist society. Routledge.

[20] Easterby-Smith, M., Lyles, M. A., \& Tsang, E. W. (2008). Inter-organizational knowledge transfer: Current themes and future prospects. Journal of management studies, 45(4), 677-690

[21] Ejdys, J. (2014). Future oriented strategy for SMEs. Procedia-Social and Behavioral Sciences, 156, 8-12.

[22] Ernst, H., \& Lichtenthaler, U. (2009). Innovation portfolio management: an understudied driver of innovation success?. International Journal of Technology Intelligence and Planning, 5(2), 111-117.

[23] Flynn, M., Dooley, L., O'sullivan, D., \& Cormican, K. (2003). Idea management for organisational innovation. International Journal of innovation management, 7(04), 417-442.

[24] Hewlett, S. A., Marshall, M., \& Sherbin, L. (2013). How diversity can drive innovation. Harvard Business Review, 91(12), 30-30.

[25] Hii, J., \& Neely, A. (2000). Innovative capacity of firms: on why some firms are more innovative than others. 7th International Annual EurOMA Conference 2000, Ghent, Belgium

[26] Hostetter, M., Klein, S., \& McCarthy, D. (2014). Taking Digital Health to the Next Level. The Commonwealth Fund

[27] lammarino, S., Sanna-Randaccio, F., \& Savona, M. (2009). The perception of obstacles to innovation. Foreign multinationals and domestic firms in Italy. Revue d'économie industrielle, (125), 75-104.

[28] Jarle Gressgård, L. (2011). Virtual team collaboration and innovation in organizations. Team Performance Management: An International Journal, 17(1/2), 102-119.

[29] Klingebiel, R., \& Rammer, C. (2014). Resource allocation strategy for innovation portfolio management. Strategic Management Journal, 35(2), 246-268. 
[30] Knosková, L. (2015). Innovation processes and entrepreneurial culture for radical innovations. Amfiteatru Economic, 17(38), 342.

[31] Komninos, N., Sefertzi, E., \& Tsarchopoulos, P. (2006). Virtual innovation environment for the exploitation of R\&D. Intelligent Environments, 6, 95-104.

[32] Kostadinović, I., \& Petrović-Ranđelović, M. (2015). The Importance of Improving The Competitiveness of The SMEEs for Development of The Economy of Republic of Serbia/Značaj unapređenja konkurentnosti sektora MSPP za razvoj privrede Republike Srbije. Economic Themes, 53(2), 247-266.

[33] Lane, J. P., \& Flagg, J. L. (2010). Translating three states of knowledge-discovery, invention, and innovation. Implementation Science, 5(1), 9.

[34] Lawson, B., \& Samson, D. (2001). Developing innovation capability in organisations: a dynamic capabilities approach. International journal of innovation management, 5(03), 377-400.

[35] Likar, B., \& Fatur, P. (2007). Managing innovation and R\&D processes in EU environment. Korona plus-Institute for Innovation and Technology.

[36] Malouf, A., Selaković, M., \& Ljepava, N. (2016): Exploring the relationship between corporate volunteering and internal communications in multinational organizations. Communications Management Review, 1(2), 6-22.

[37] Mandarić, M. (2012). Strategijski brend menadžment kao faktor konkurentnosti kompanija (Doctoral dissertation, Univerzitet u Kragujevcu-Ekonomski fakultet)

[38] Maniak, R., \& Midler, C. (2014). Multiproject lineage management: Bridging project management and design-based innovation strategy. International Journal of Project Management, 32(7), 1146-1156.

[39] Martin, L. M., \& Matlay, H. (2003). Innovative use of the Internet in established small firms: the impact of knowledge management and organisational learning in accessing new opportunities. Qualitative Market Research: An International Journal, 6(1), 18-26.

[40] McAdam, R., \& McClelland, J. (2002). Individual and team-based idea generation within innovation management: organisational and research agendas. European Journal of Innovation Management, 5(2), 86-97.

[41] Milojević, S., Todorović, V., \& Lutovac, M. (2016). Brand as a challenge to corporate governance in the globalization process. Marketing, 47(1), 57-65.

[42] Newell, S., Robertson, M., Scarbrough, H., \& Swan, J. (2009). Managing knowledge work and innovation. Palgrave Macmillan.

[43] Palmberg, C. (2006). The sources and success of innovations-Determinants of commercialisation and break-even times. Technovation, 26(11), 1253-1267.

[44] Prester, J. (2010). Menadžment inovacija. Sinergija.

[45] Punia, B. K. (2014). Relatedness of Personal and Familial Factors with Cultural Attitude of Aspiring Managers: A Comparative Study. International Journal, 2(3).

[1] Radovanović, N. (2014). Upravljanje kapacitetom apsorpcije znanja kao faktor konkurentnosti organizacije (Doctoral dissertation, Univerzitet u Beogradu-Fakultet organizacionih nauka).

[1] Roberts, E. B. (2007). Managing invention and innovation. Research-Technology Management, 50(1), 35-54.

[1] Sabolović-Krajina, D. (2015). Inovativnost u knjižnicama-primjer prakse Knjižnice i čitaonice "Fran Galović" Koprivnica. Vjesnik bibliotekara Hrvatske, 58(1-2), 305-319.

[1] Selaković, M. (2017). Relevance of the Organizational Knowledge Preservation and Development for Efficient Stakeholder Communication. DOBA Faculty for Applied Business and Social Sciences

[1] Simon, H. (2009). Hidden champions of the twenty-first century: The success strategies of unknown world market leaders. Springer Science \& Business Media. 
[1] Souder, W. E. (1988). Managing relations between R\&D and marketing in new product development projects. Journal of product innovation management, 5(1), 6-19.

[1] Stanković, L., Đukić, S., Mladenović, I., \& Popović, A. (2011). Unapređenje poslovne konkurentnosti preduzeća zasnovano na inovacijama. Ekonomske teme, 49(4), 559-580.

[1] Stefik, M., \& Stefik, B. (2004). Breakthrough: stories and strategies of radical innovation. MIT press.

[1] Stošić, B. (2007). Menadžment inovacija: Ekspertni sistemi, modeli i metode. Fakultet organizacionih nauka.

[1] Stošić, B., \& Jeremić, I. (2007). Upravljanje inovacijama primenom modela 'faza-kapija'. Tehnička dijagnostika, 6(2), 41-46.

[1] Tao, L., Probert, D., \& Phaal, R. (2010). Towards an integrated framework for managing the process of innovation. R\&d Management, 40(1), 19-30.

[1] Teodorescu, G. (2015). Cascade Innovation, a Model of a Romanian, Original Business Economy. EIRP Proceedings, 10.

[1] Thompson, V. A. (1965). Bureaucracy and innovation. Administrative science quarterly, 1-20.

[1] Tonnessen, T. (2005). Continuous innovation through company wide employee participation. The TQM Magazine, 17(2), 195-207.

[1] Trott, P. (2008). Innovation management and new product development. Pearson education.

[1] Williams, A. (1999). Creativity, invention and innovation. Sydney: Allen \& Unwin, 15(10), 10. 